\title{
TWO PASSAGES IN THE LAST SCENE OF OTHELLO
}

(1) v. ii. $71 \mathrm{f}$. Desdemona demands that Cassio be sent for to 'confess' the truth that she never gave him the handkerchief. Othello answers that Cassio has confessed the truth - has confessed the adultery. The dialogue goes on:

Des. He will not say so.

Oth.

No, his mouth is stopp'd:

Honest Iago hath ta'en order for 't.

Des. O! my fear interprets: what, is he dead?

Oth. Had all his hairs been lives, my great revenge Had stomach for them all.

Des. Alas! he is betray'd and I undone.

It is a ghastly idea, but I believe Shakespeare means that, at the mention of Iago's name, Desdemona suddenly sees that $h e$ is the villain whose existence he had declared to be impossible when, an hour before, Emilia had suggested that someone had poisoned Othello's mind. But her words rouse Othello to such furious indignation ('Out, strumpet! Weep'st thou for him to my face?') that 'it is too late'.

(2) v. ii. $286 \mathrm{f}$.

Oth. I look down towards his feet; but that's a fable. If that thou be'st a devil, I cannot kill thee.

Lod. Wrench his sword from him.

[Wounds Iago Iago.

I bleed, sir, but not killed.

Are Iago's strange words meant to show his absorption of interest in himself amidst so much anguish? I think rather he is meant to be alluding to Othello's words, and saying, with a cold contemptuous smile, 'You see he is right; I am a devil'. 